\title{
Genomic and Physiological Properties of a Facultative Methane-Oxidizing Bacterial Strain of Methylocystis sp. from a Wetland
}

\author{
Gi-Yong Jung ${ }^{1,2}$, Sung-Keun Rhee ${ }^{2}$, Young-Soo $\mathrm{Han}^{3}$ and So-Jeong Kim ${ }^{1, * \mathbb{C}}$ \\ 1 Geologic Environment Research Division, Korea Institute of Geoscience and Mineral Resources, \\ Daejeon 34132, Korea; seraphim0123@gmail.com \\ 2 Department of Microbiology, Chungbuk National University, Cheongju 28644, Korea; rhees@chungbuk.ac.kr \\ 3 Department of Environmental Engineering, Chungnam National University, Daejeon 34134, Korea; \\ hanyoungsoo@cnu.ac.kr \\ * Correspondence: sojkim86@kigam.re.kr; Tel.: +82-42-868-3311; Fax: +82-42-868-3414
}

Received: 2 September 2020; Accepted: 30 October 2020; Published: 2 November 2020

\begin{abstract}
Methane-oxidizing bacteria are crucial players in controlling methane emissions. This study aimed to isolate and characterize a novel wetland methanotroph to reveal its role in the wetland environment based on genomic information. Based on phylogenomic analysis, the isolated strain, designated as B8, is a novel species in the genus Methylocystis. Strain B8 grew in a temperature range of $15^{\circ} \mathrm{C}$ to $37^{\circ} \mathrm{C}$ (optimum $30-35^{\circ} \mathrm{C}$ ) and a $\mathrm{pH}$ range of 6.5 to 10 (optimum 8.5-9). Methane, methanol, and acetate were used as carbon sources. Hydrogen was produced under oxygen-limited conditions. The assembled genome comprised of $3.39 \mathrm{Mbp}$ and $59.9 \mathrm{~mol} \% \mathrm{G}+\mathrm{C}$ content. The genome contained two types of particulate methane monooxygenases (pMMO) for low-affinity methane oxidation (pMMO1) and high-affinity methane oxidation (pMMO2). It was revealed that strain B8 might survive atmospheric methane concentration. Furthermore, the genome had various genes for hydrogenase, nitrogen fixation, polyhydroxybutyrate synthesis, and heavy metal resistance. This metabolic versatility of strain B8 might enable its survival in wetland environments.
\end{abstract}

Keywords: methanotrophic bacteria; genome of Methylocystis; wetland; methane monooxygenase

\section{Introduction}

Wetlands, including bogs, marshes, and swamps, are typical areas where the methane cycle occurs actively and play a role in the carbon cycle $[1,2]$. Owing to methane production by methanogens, eutrophic wetlands are the main channel of methane fluxes [3,4]. Methane diffuses throughout wetlands [5,6] and creates a suitable environment for methanotrophs. Methanotrophic metabolism contributes to carbon cycling in wetland ecosystems $[7,8]$. The emission of methane is a major contributor to the greenhouse effect [9]. The importance of methanotrophic microorganisms in wetland carbon cycling and methane emissions has spurred investigations to identify and characterize aerobic methanotrophs.

Type I (including a subdivision of type X) methanotrophs belong to the class Gammaproteobacteria and Type II methanotrophs belong to the class Alphaproteobacteria $[10,11]$. Methanotrophs belonging to Verrucomicrobia were discovered in acidic thermal environments. Methane oxidation by methane monooxygenase is the first and most critical step in methane metabolism [12-14]. Methane is oxidized by particulate methane monooxygenase (pMMO) and soluble methane monooxygenase (sMMO) [15]. Whereas pMMO is bound to the cell membrane, sMMO exists in the cytoplasm [15]. Both $\mathrm{pMMO}$ and sMMO require distinct metal elements as a prosthetic group (copper ions and iron ions, respectively) [16-18]. Methanol is oxidized to formaldehyde by methanol dehydrogenase [19]. 
Formaldehyde is oxidized by several enzymes, including the formaldehyde-activating enzyme, through the methylene tetrahydromethanopterin $\left(\mathrm{H}_{4} \mathrm{MPT}\right)$ pathway $[20,21]$. Formate is oxidized by formate dehydrogenase to supply electrons to NAD [22]. Formaldehyde and formate are used as carbon sources depending on the methanotroph. In the RuMP pathway of type I methanotrophs, formaldehyde is used for cellular carbon production. Formaldehyde and ribulose 5-phosphate are converted to hexulose 6-phosphate through the pentose phosphate pathway, which is used to synthesize cellular carbohydrates. In the serine pathway of type II methanotrophs, formate is converted to methylenetetrahydrofolate (THF) and used for carbon metabolism [22].

Methanotrophs are not only able to reduce methane but can also produce value-added substances [23]. Recently, methanotrophs have become a promising option for mitigating methane emission [24]. Methylocystis parous OBBP was known as one of the candidates for the cell factory production of Polyhydroxybutyrate (PHB) [25]. Other studies have been conducted on the synthesis of PHB by methane-oxidizing bacteria [26]. The production of organic acids (formate, acetate, lactate, and succinate) and hydrogen in Methylomicrobium alcaliphilum $20 \mathrm{Z}$ was considered a potential biocatalysis based on methane [27].

The genus Methylocystis includes type II methanotrophs belonging to the class Alphaproteobacteria and family Methylocystaceae [28]. The genus Methylocystis was first identified in 1970 [29] and was later validated by Bowman et al. [28]. The genus Methylocystis includes six species: M. rosea [30], M. hirsuta [31], M. bryophila [32], M. echinoides, M. parous [28], and M. heyeri [33]. These species have been isolated from various environments, including groundwater aquifers, acidic peat-bog lakes, and wetland soils. Several Methylocystis genomes have been reported [34-38].

Methanotrophs were initially known as microorganisms which used only methane and methanol as carbon and energy sources. However, starting with Methylocella palustris, among the verified strains, it has been reported that facultative methanotrophs could utilize compounds with carbon-carbon bonds. The genus Methylocystis included some facultative methanotrophic species. The common source of multi-carbon was acetate. A study assumed that acetate utilization might be important for survival in environments where methane availability is variable or limited [39]. Such cases included wetlands and upland soils. Methylocystis spp. were predominant in these environments [40,41].

In this study, a novel methanotroph was isolated from a wetland and characterized to reveal its role in methane cycling in this environment. Genome properties were revealed using comparative genomics. The physiological and genomic data provide insight into the adaptations of Methylocystis methanotrophs in wetland environments.

\section{Materials and Methods}

\subsection{Enrichment Culture and Isolation}

A water sample was obtained from an artificial wetland in Ok-Cheon, Republic of Korea (36.19 N, 127.33 E) in June 2017. Temperature, electrical conductivity (EC), oxidation-reduction potential (ORP), $\mathrm{pH}$, and dissolved oxygen (DO) of sampled water were checked by a Multimeter (HQ40d, Hach, Loveland, CO, USA) onsite. To examine the water composition, the water was filtered with a syringe filter $(0.45 \mu \mathrm{m}$ pore size) and analyzed with ion chromatography (IC, Metrohm, Herisau, Switzerland) and inductively coupled plasma-optical emission spectrometry (ICP-OES, Horiba Jobin Yvon, Longjumeau, France). The $50 \mathrm{~mL}$ sample was filtered through a $0.1 \mu \mathrm{m}$ pore polycarbonate (PC) filter membrane to collect cells. The collected cells were incubated in $10 \mathrm{~mL}$ of modified nitrate mineral salt (NMS) medium in a Balch-type tube (CLS-4209, Chemglass, Vineland, NJ, USA) at $25^{\circ} \mathrm{C}$. Methane (filter sterilized, $0.22 \mu \mathrm{m}$ pore size) was added to the headspace air $(15 \%, v / v)$ through a syringe. One liter of the medium contained $0.0985 \mathrm{~g} \mathrm{MgSO}_{4} \cdot 7 \mathrm{H}_{2} \mathrm{O}, 0.0147 \mathrm{~g}$ $\mathrm{CaCl}_{2} \cdot 2 \mathrm{H}_{2} \mathrm{O}, 0.0348 \mathrm{~g} \mathrm{~K}_{2} \mathrm{SO}_{4}, 0.017 \mathrm{~g} \mathrm{NaNO}_{3}, 0.0136 \mathrm{~g} \mathrm{KH}_{2} \mathrm{PO}_{4}, 0.252021 \mathrm{~g} \mathrm{NaHCO}, 1 \mathrm{~mL}$ SL-10 trace element solution [42], $1 \mathrm{~mL}$ vitamin solution [43], and $0.028 \mathrm{~g}$ cerium [44]. The culture was serially diluted from $10^{-1}$ to $10^{-10}$ several times. Furthermore, the dilution-to-extinction cultivation 
method was conducted in 96-well plates. The emerging turbidity among the wells was used for isolation using the floating membrane method with the polycarbonate membrane $(0.1 \mu \mathrm{m}$ pore size $)$ on the NMS medium at various methanol concentrations $(0.1 \%, 0.5 \%$, and $1 \%)$ at $25^{\circ} \mathrm{C}$. After 2 weeks, small colonies were observed on the floating membrane. The isolated cell was named B8. Cells were routinely cultured in a modified NMS medium. The purity of culture was checked by monitoring the T-RFLP of 16S rRNA gene PCR product [45] from cultures grown with either methane or acetate after incubation. In addition, no growth was confirmed in the modified NMS medium with $0.1 \%$ yeast extract as the sole energy source. Furthermore, contamination by other heterotrophic bacteria was routinely checked on nutrient agar and R2A agar plates.

\subsection{Physiologic Analysis}

Gram staining was performed using a commercial kit (BD, Franklin Lakes, NJ, USA). Cell morphology and cell size were observed by differential interference contrast microscopy (Axio Scope.A1; Carl Zeiss, Jena, Germany). Catalase and oxidase tests were performed with 3\% hydrogen peroxide $\left(\mathrm{H}_{2} \mathrm{O}_{2}\right)$ and oxidase strips (Sigma-Aldrich. St. Louis, MO, USA), respectively. Strain B8 was grown at $4{ }^{\circ} \mathrm{C}, 10^{\circ} \mathrm{C}, 15^{\circ} \mathrm{C}, 20^{\circ} \mathrm{C}, 25^{\circ} \mathrm{C}, 30^{\circ} \mathrm{C}, 35^{\circ} \mathrm{C}, 37^{\circ} \mathrm{C}, 40^{\circ} \mathrm{C}$, and $45^{\circ} \mathrm{C}$. NaCl tolerance was assessed by growth in the presence of $0 \%$ to $5 \% \mathrm{NaCl}$ (in $0.5 \%$ increments). The $\mathrm{pH}$ was tested from 4 to 12 in increments of 0.5 . To identify nitrogen sources used by strain B8, the sample was incubated in a modified NMS medium with various nitrogen sources (cysteine, yeast extract, casamino acid, betaine, carsitone, and ammonium sulfate) by replacing $0.05 \%(w / v)$ sodium nitrate. Carbon source utilization was assessed using $0.05 \%$ ethanol, glucose, acetate, or pyruvate. Tests were performed in duplicates. Colony formation was checked on the solid medium containing $1.5 \%$ agarose, $1 \%$ phytagel, and 1\% gellan gum. PHB formation was estimated using Nile Red staining followed by examination using an Axio Scope A1 fluorescence microscope (Carl Zeiss, Oberkochen, Germany). To calculate the growth rate, strain B8 was cultured in a modified NMS medium with added methane $(15 \%, v / v)$ at $30{ }^{\circ} \mathrm{C}$ and $150 \mathrm{rpm}$. The growth rate was monitored in triplicates. The methane concentration in headspace and cell growth was measured for 7 days. Cell growth (optical density at 600 nm, OD 600 ) was determined using spectrophotometers (Optizen POP; Mecasys, Daejeon, Korea and Spectra Max 190 microplate reader; Molecular Devices, CA, USA). Methane was measured by gas chromatography (GC). The detailed condition was described in Section 2.3. Also, the quantity of 16S rRNA and pmoA gene was measured by Q-PCR (CFX96 Real-time System, Bio-rad, Hercules, CA, USA) with primers Bac518F/Bac786R [46] and A189F/A682R [47], respectively.

\subsection{Hydrogen Utilization Test}

Hydrogen utilization was evaluated in a modified NMS medium with a $\% \mathrm{H}_{2}$ amended or $\mathrm{H}_{2}$ nonamended headspace and various methane and oxygen concentration based on Hakobyan et al. [48]. The conditions were as follows. Set1: 20\% methane and 15\% oxygen; Set2: 20\% methane and 3\% oxygen; Set3: $6 \%$ methane and 15\% oxygen; set $4: 6 \%$ methane and 3\% oxygen; and set5: $20 \%$ methane and $9 \%$ oxygen. Before gas injection, headspace was replaced with Ar gas. Then, all gases were injected with a syringe through a syringe filter $(0.22 \mu \mathrm{m}$ pore size $)$ for sterilization. The hydrogen and methane concentration and $\mathrm{OD}_{600}$ were measured during the incubation time.

Methane and hydrogen concentrations in the headspace were monitored by a GC-flame ionization detector/thermal conductivity detector (GC-FID/TCD, Agilent 6890N, Santa Clara, CA, USA) using a $12390-\mathrm{U}$ column. The temperature of the injector was at $200{ }^{\circ} \mathrm{C}$ isothermally. The oven temperature was maintained at $65^{\circ} \mathrm{C}$ for $1 \mathrm{~min}$, then ramped at a rate of $25^{\circ} \mathrm{C} / \mathrm{min}$ to $225^{\circ} \mathrm{C}$ and held for $2 \mathrm{~min}$. The temperatures of FID and TCD were $250^{\circ} \mathrm{C}$ and $230^{\circ} \mathrm{C}$, respectively. The methane and hydrogen were determined with $200 \mu \mathrm{L}$ of gaseous sample of the headspace of the bottle. 


\subsection{Phylogenetic Analysis}

The genome was extracted using a DNA extraction kit (QIAGEN, Valencia, CA, USA). The $16 \mathrm{~S}$ ribosomal RNA gene was amplified using 27F/1492R primers [49,50], and the methane monooxygenase gene was amplified using A189F/A682R [47], mmox1/mmox2 [51], and mmox206F/mmox886R [52] primers. PCR conditions were as previously described $[47,51,52]$. Phylogenetic trees based on $16 \mathrm{~S}$ rRNA genes and $p m o A$ genes aligned using Bioedit were constructed using the neighbor-joining method [53] in MEGA 7 [54] based on the Kimura 2-parameter model and Poisson model using 1000 replicates, respectively. The $16 \mathrm{~S}$ rRNA gene similarity was calculated using EzBioCloud [55].

\subsection{Genomic Analysis}

A paired-end DNA library was constructed using a Truseq Nano DNA kit (Illumina, San Diego, CA, USA). Sequencing was performed by an Illumina HiseqX device at Macrogen (Seoul, Korea). The quality of the raw reads was checked by FastQC. SPAdes (ver. 3.13) was used to assemble the raw reads [56]. The assembled methanotroph scaffolds were annotated using the NCBI Prokaryotic Genome Annotation Pipeline [57]. Gene function was analyzed using BLASTp [58] against the nonredundant (NR) database and the Kyoto Encyclopedia of Genes and Genomes [59]. A domain search was performed using PfamScan [60]. Clusters of orthologous groups (COG) classification was performed according to bac-genomics-scripts (https://github.com/aleimba/bac-genomics-scripts). The average nucleotide identities (ANI) of B8 and other Methylocystis species were analyzed using orthologous average nucleotide identity tool (OAT) software [61]. Average amino acid identity (AAI) was calculated using CompareM (https://github.com/dparks1134/CompareM). Pan-genome analysis was performed using PGAP (ver. 1.2.1) [62]. The phylogenomic tree was reconstructed using Anvio-6.1 (default parameter and hmm source: Bacteria_71) [63]. The antibiotic resistance genes were analyzed using a comprehensive antibiotic resistance database (CARD) [64].

\subsection{Data Availability}

The $16 \mathrm{~S}$ rRNA gene and draft genome were deposited in the NCBI GenBank as accession numbers MN527243 and VBTZ00000000, respectively.

\section{Results and Discussion}

\subsection{Information on Sampling Site}

The artificial wetland in Ok-Cheon, Republic of Korea (36.19 N, 127.33 E) was constructed to remove nonpoint source pollution from the Daecheong lake, a source of drinking and irrigation water [65]. The water composition of the artificial wetland at the sampling time was summarized in Table 1 . The temperature was over $15^{\circ} \mathrm{C}$, except for the winter season [66].

\subsection{Physiological Characterization}

Cells of strain B8 were $0.7 \mu \mathrm{m}$ in width and $1.5 \mu \mathrm{m}$ in length. Cells were gram-negative, oxidaseand catalase-positive, coccobacilli or short rod-shaped, and appeared as single cells or in aggregates, but not as rosettes. PHB formation was observed by fluorescence microscopy of Nile Red stained sections (Supplementary Figure S1). Colonies did not form on NMS agar, gellan, or phytagel plates. The harvested cell pellet was creamy white. Strain B8 grew between $15^{\circ} \mathrm{C}$ and $37^{\circ} \mathrm{C}$, with optimal growth at $30-35{ }^{\circ} \mathrm{C}$. The bacteria were not tolerant to high salinity and grew between $0 \%$ to $0.5 \% \mathrm{NaCl}$ concentration. Growth occurred at $\mathrm{pH}$ values ranging from $\mathrm{pH} 6.5$ to 10 . The optimal $\mathrm{pH}$ was 8.5 to 9 , indicating that strain B8 is slightly alkaliphilic. Nitrate ammonia, yeast extract, and cysteine were used as nitrogen sources, while carsitone, casamino acid, and betaine were not. Growth rate was $0.11 \pm 0.01 \mathrm{~h}^{-1}$ in the modified NMS medium with methane $(20 \%, v / v)$ at $30^{\circ} \mathrm{C}$ and $150 \mathrm{rpm}$. Strain B8 could use methanol at levels ranging from $0.05 \%$ to $1 \%$. The optimum level was $0.1 \%$. Ethanol, 
glucose, and pyruvate were not used as carbon sources. Methane and methanol were the carbon and energy sources for strain B8. In addition, growth was observed using acetate as a carbon and energy source after 1 month of incubation. This result was also reported from other facultative methanotrophs, such as M. bryophila H2s, M. heyeri H2, M. echinoides IMET10491 [39], and Methylocystis sp. SB2 [67]. It might serve as a survival strategy in environments with limited methane concentration, such as peat [39]. Table 2 summarizes the findings and compares them with close relatives identified using the phylogenetic analysis described. The physiological properties of strain B8 indicate that this strain is slightly alkaliphilic compared to other members of Methylocystis. This might be advantageous in the development of alkaline conditions during photosynthesis in wetlands [68]. Strain B8 was deposited in the Korean Collection for Type Cultures (KCTC) as KCTC82145.

Table 1. The properties of sampling water.

\begin{tabular}{cc}
\hline Properties & Sampling Water \\
\hline Sampling date & 29 Jun 2017 \\
Temperature $\left({ }^{\circ} \mathrm{C}\right)$ & 26.1 \\
$\mathrm{pH}$ & 6.46 \\
$\mathrm{EC}(\mu \mathrm{S} / \mathrm{cm})$ & 670 \\
$\mathrm{DO}(\mathrm{mg} / \mathrm{L})$ & 6.82 \\
$\mathrm{ORP}(\mathrm{mV})$ & 84.7 \\
$\mathrm{Ca}^{2+}(\mathrm{mg} / \mathrm{L})$ & 23.58 \\
$\mathrm{~K}^{+}(\mathrm{mg} / \mathrm{L})$ & 16.43 \\
$\mathrm{Mg}^{2+}(\mathrm{mg} / \mathrm{L})$ & 6.49 \\
$\mathrm{Na}^{+}(\mathrm{mg} / \mathrm{L})$ & 83.71 \\
Fluoride $(\mathrm{mg} / \mathrm{L})$ & 3.19 \\
$\mathrm{Chloride}(\mathrm{mg} / \mathrm{L})$ & 151.56 \\
Nitrite $(\mathrm{mg} / \mathrm{L})$ & 1.7 \\
Nitrate $(\mathrm{mg} / \mathrm{L})$ & 26.48 \\
Sulfate $(\mathrm{mg} / \mathrm{L})$ & 33.22 \\
\hline
\end{tabular}

Table 2. Characteristics of Methylocystis sp. B8 and related strains in Methylocystis.

\begin{tabular}{|c|c|c|c|c|c|c|c|}
\hline & 1 & 2 & 3 & 4 & 5 & 6 & 7 \\
\hline Cell size $(\mu \mathrm{m})$ & $0.7 \times 1.5$ & $\begin{array}{c}0.3-0.6 \times \\
0.7-1.0\end{array}$ & $\begin{array}{l}0.8-1.1 \times \\
1.1-2.5\end{array}$ & $0.5 \times 0.5-2.0$ & $0.5 \times 0.5-1.0$ & $\begin{array}{c}0.9-1.4 \times \\
1.8-3.4\end{array}$ & $0.8-1.2 \times 1.4-4.0$ \\
\hline Cell shape & Rod & Dumbbell & Rod & $\begin{array}{l}\text { Coccobacillus, } \\
\text { rod }\end{array}$ & $\begin{array}{l}\text { Coccobacillus, } \\
\text { rod }\end{array}$ & $\begin{array}{l}\text { Small, curved } \\
\text { coccoids, short }\end{array}$ & $\begin{array}{l}\text { straight or } \\
\text { regularly curved } \\
\text { rod, ovoid }\end{array}$ \\
\hline Colony color & Cream & Cream & Pink-red & White, buff & $\begin{array}{c}\text { Diffusion } \\
\text { brown, pale } \\
\text { pink }\end{array}$ & Light cream & White \\
\hline $\begin{array}{l}\text { Temperature } \\
\left({ }^{\circ} \mathrm{C}\right)\end{array}$ & $15-37$ & $<37$ & $5-37$ & $20-28$ & $\sim 20-37$ & $8-37$ & $5-30$ \\
\hline $\begin{array}{c}\text { Optimum } \\
\text { Temperature }\left({ }^{\circ} \mathrm{C}\right)\end{array}$ & $30-35$ & 30 & 27 & $25-28$ & $30-37$ & $25-30$ & 25 \\
\hline $\mathrm{pH}$ & $6.5-10.0$ & $4.0-9.0$ & $5.5-9.0$ & $5.0-9$ & $5.5-8.8$ & $4.2-7.6$ & $4.4-7.5$ \\
\hline Optimum pH & $8.5-9.0$ & 7.0 & NR & $6.5-7$ & 7.5 & $6.0-6.5$ & $5.8-6.2$ \\
\hline $\mathrm{NaCl}(\%)$ & $0-0.5$ & NR & $0=<$ & $0-1.0$ & $0-2.0$ & $0-0.1$ & $0-0.5$ \\
\hline $\begin{array}{l}\text { Optimum } \\
\mathrm{NaCl}(\%)\end{array}$ & $0-0.5$ & NR & NR & NR & NR & NR & NR \\
\hline Oxidase & + & + & + & + & + & + & + \\
\hline Catalase & + & + & + & + & + & + & + \\
\hline Methanol (\%) & $0.05-1$ & + & - & 0.2 & 5 & $\leq 0.15$ & $\leq 1$ \\
\hline $\begin{array}{c}\text { Optimum } \\
\text { Methanol (\%) }\end{array}$ & 0.1 & NR & - & NR & NR & NR & 0.1 \\
\hline \multicolumn{8}{|c|}{ Carbon Source } \\
\hline Ethanol & - & NR & - & NR & NR & \pm & NR \\
\hline Acetate & + & $\mathrm{w}^{*}$ & - & $\mathrm{w}^{*}$ & - & + & $\mathrm{w}^{*}$ \\
\hline Pyruvate & - & NR & NR & NR & NR & \pm & NR \\
\hline \multicolumn{8}{|c|}{ Nitrogen Source } \\
\hline Cysteine & + & NR & NR & - & - & + & - \\
\hline Yeast extract & + & NR & NR & + & + & + & + \\
\hline
\end{tabular}


Table 2. Cont.

\begin{tabular}{cccccccc}
\hline & $\mathbf{1}$ & $\mathbf{2}$ & $\mathbf{3}$ & $\mathbf{4}$ & $\mathbf{5}$ & $\mathbf{6}$ & $\mathbf{7}$ \\
\hline Casamino acid & - & $\mathrm{NR}$ & $\mathrm{NR}$ & + & + & $\mathrm{NR}$ & $\mathrm{NR}$ \\
Betaine & - & $\mathrm{NR}$ & $\mathrm{NR}$ & - & - & $\mathrm{NR}$ & $\mathrm{NR}$ \\
Carsitone & - & $\mathrm{NR}$ & $\mathrm{NR}$ & $\mathrm{NR}$ & $\mathrm{NR}$ & $\mathrm{NR}$ & $\mathrm{NR}$ \\
$\left(\mathrm{NH}_{4}\right)_{2} \mathrm{SO}_{4}$ & + & $\mathrm{NR}$ & + & + & + & + & + \\
Nitrate & + & + & + & + & + & + & + \\
\hline
\end{tabular}

Strains: 1, Methylocystis sp. B8 (this study); 2, Methylocystis hirsuta CSC1 ${ }^{\mathrm{T}}$ [31]; 3, Methylocystis rosea SV97 ${ }^{\mathrm{T}}$ [30];

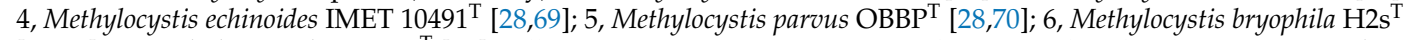
$[32,39] ; 7$, Methylocystis heyeri $\mathrm{H} 2^{\mathrm{T}}$ [33]. All strains were gram-negative and non-motile. The characteristics of B8 and other species, Methylocystis, are provided. +, Positive reaction; -, negative reaction; w, weakly positive; \pm , trace growth; NR, not reported. * Data from Belova et al. [39].

\subsection{Hydrogen Utilization and Production}

The hydrogen utilization test was conducted using various methane and oxygen conditions. Recently, it was reported that Methylocystis sp. SC2 uses hydrogen as an energy source [48]. The growth yield increased significantly under $6 \% \mathrm{CH}_{4}$ and $3 \% \mathrm{O}_{2}$ conditions when $2 \% \mathrm{H}_{2}$ was added to headspace culture. However, the effect was not observed using strain B8. Instead, hydrogen was produced when oxygen decreased to an oxygen limitation level without gas exchange (Supplementary Figure S2). A similar result was found for Methylomonas sp. DH-1 [71] and Methylomicrobium alcaliphilum 20Z [27], which are type I methanotrophs. GC results showed that this result was related to the type of hydrogenase in Methylocystis sp. B8. For additional information, see Section 3.9.

\subsection{Genomic Features}

The genomic information of strain B8 is shown in Table 3. The G + C content was $59.9 \%$ and the lowest in the genomes of the Methylocystis species. Genes of the genome were classified according to function using COG analysis (Supplementary Table S1). Genes with 'no functional prediction' (S) were most prevalent $(13 \%)$, followed by those with 'general function prediction only' $(\mathrm{R}, 11 \%)$ and related to 'energy production and conversion' (C, 8\%). Contigs 10 (116,387 bp) and 12 (92,240 bp) displayed a cluster of plasmid replication genes $($ rep $A, \operatorname{rep} B$, and repC), respectively. Genes in the clusters FEV16_14560-FEV16_14570 and FEV16_15250-FEV16_15260 of strain B8 were homologous with P1_12-P1_14 and P2_74-76 of Methylocystis sp. SC2. These findings indicate that the two contigs belong to a plasmid, further indicating that strain B8 might harbor two large plasmids. Contig 10 also contained mercury reductase genes similar to those of strain SC2 [72].

\subsection{Phylogeny}

Phylogenetic analysis of the 16S rRNA gene sequence showed that strain B8 clustered with the genus Methylocystis in Alphaproteobacteria. Strain B8 was closely related to M. hirsuta CSC1 ${ }^{\mathrm{T}}$, M. rosea SV97 ${ }^{\mathrm{T}}$, and M. echinoides IMET10491 ${ }^{\mathrm{T}}$ with $98.8 \%, 98.4 \%$, and $97.9 \% 16 \mathrm{~S}$ rRNA gene similarity, respectively (Supplementary Figure S3). The genome closest to that of strain B8 was Methylocystis sp. SC2 (HE956757), with the highest ANI value of $84.76 \%$. The lowest ANI value (73.06) was observed in the genome of M. bryophila. The highest and lowest AAI values were obtained with Methylocystis rosea BRCS1 (86.9\%) and M. bryophila S285 (68.5\%), respectively (Supplementary Table S2). The ANI and AAI results, combined with the phylogenetic analysis results based on 16S rRNA gene sequences, indicate that strain B8 is a novel species in the genus Methylocystis based on the threshold values suggested by Konstantidis and Tiedje [73] and Konstantidis et al. [74]. The AAI result showed that genomes of 16 species in Methylocystis have been reported or deposited (in NCBI) so far. Furthermore, the phylogenomic tree was reconstructed with genomes of Methylocystis, Methylosinus, and other genera in the Methylocystaceae family (Figure 1). It supported that strain B8 is a new species in the genus Methylocystis. Furthermore, we suggest that Methylocystis sp. LW5 should be reclassified as a member of the genus Methylosinus based on the phylogenomic tree. 


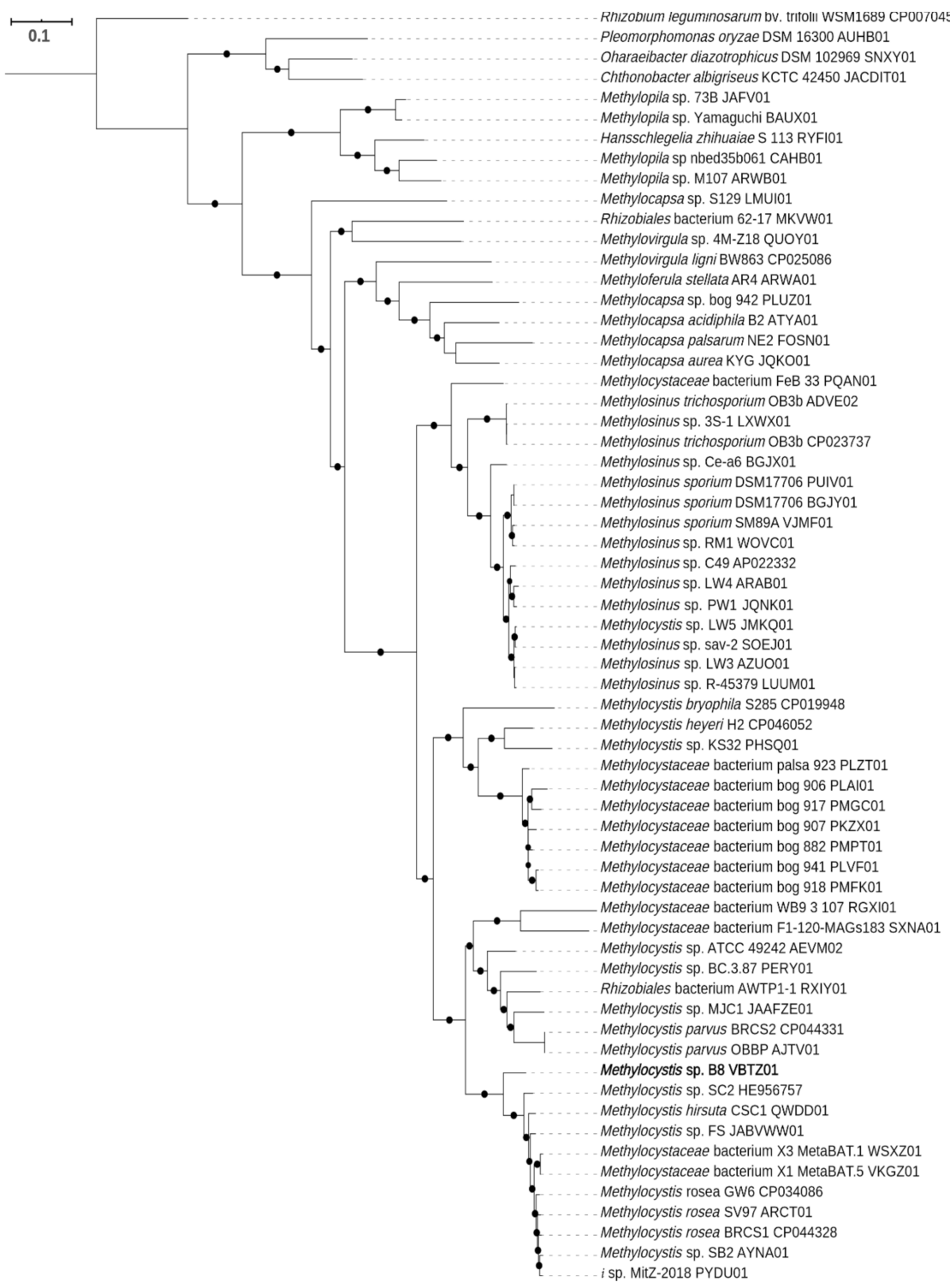

Figure 1. The phylogenetic tree of Methylocystis sp. B8 and other strains in the family Methylocystaceae based on concatenated conserved proteins. The outgroup was Rhizobium leguminosarum bv. trifolii in the family Rhizobiaceae. Closed circles indicate the bootstrap values $\geq 70 \%$.

\subsection{Pangenome Analysis}

Eleven strains of Methylocystis (Table 3) were compared based on the pan-genome analysis. The Methylocystis pan-genome consisted of 13,554 clusters with 1537 core gene clusters in our study. A total of 328 clusters (335 genes) were identified as unique genes in strain B8 (Supplementary Table S3). The COG classification of the unique genes showed that major COGs were assigned to $\mathrm{R}$ (general functional prediction), $\mathrm{S}$ (function unknown), and $\mathrm{M}$ (cell wall, membrane, and envelope biogenesis). As COG M predominantly includes genes for lipopolysaccharide production, these genes might be related to niche adaptation by modifying the surface structures of cells [75]. Recently, another study intensively analyzed the pangenome analysis in the genus Methylocystis/Methylosinus [76]. Briefly, the genera Methylocystis and Methylosinus had encoding genes related to methane oxidation and nitrogen fixation. However, their types were different between species. One of the major differences between Methylocystis and Methylosinus was motility. Furthermore, some species in the genus Methylocystis had metabolic flexibility, such as growth on acetate and ethanol as carbon and energy sources, as well as having photosynthetic-related genes. 
Table 3. Genomic features of Methylocystis sp. B8 and other strains of Methylocystis.

\begin{tabular}{|c|c|c|c|c|c|c|c|c|c|c|c|}
\hline & 1 & 2 & 3 & 4 & 5 & 6 & 7 & 8 & 9 & 10 & 11 \\
\hline $\begin{array}{l}\text { Genome size } \\
\text { (bp) }\end{array}$ & $3,409,164$ & $4,726,034$ & $4,213,043$ & $3,773,444$ & $3,912,050$ & $4,475,912$ & $3,359,940$ & $4,707,971$ & $4,690,566$ & $4,364,363$ & $3,644,633$ \\
\hline GC content & 59.9 & 62.8 & 62.4 & 63.4 & 62.5 & 63.4 & 63.1 & 63.1 & 63 & 62.5 & 62.7 \\
\hline N50 (bp) & 386,567 & $3,131,807$ & $3,776,027$ & $3,773,444$ & $1,614,040$ & 95,607 & 917.805 & $4,532,950$ & $3,287,239$ & 136,571 & 54,643 \\
\hline Coverage $(x)$ & 132.6 & 30 & 252.0 & 53 & unknown & 33 & 280.0 & 34.7 & 53.0 & 60 & 2.0 \\
\hline Contig number & 28 & 7 & 4 & 1 & 4 & 108 & 9 & 2 & 12 & 55 & 158 \\
\hline $\begin{array}{l}\text { Protein coding } \\
\text { genes }\end{array}$ & 3176 & 4307 & 4036 & 3583 & 3709 & 4160 & 3576 & 4148 & 3987 & 4043 & 3433 \\
\hline $\begin{array}{c}\text { rRNA } \\
\text { operons }\end{array}$ & 3 & 6 & 3 & 3 & 3 & 3 & NR & 6 & 5 & 3 & 16 \\
\hline $\begin{array}{l}\text { tRNA } \\
\text { genes }\end{array}$ & 47 & 53 & 49 & 47 & 50 & 46 & NR & 47 & 54 & 50 & 45 \\
\hline $\begin{array}{c}\text { Genbankaccession } \\
\text { number }\end{array}$ & JBTZ00000000 & AEVM00000 & QWDD0000 & HE956757 & ARCT0000000 & AJTV00000000 & PHSQ00000000 & СР019948 & SOPH000000 & PYDU00000000 & AYNA00000000 \\
\hline
\end{tabular}

number $\mathrm{H} 2 \mathrm{~s}^{\mathrm{T}} ; 9$, M. heyeri $\mathrm{H}_{2}^{\mathrm{T}} ; 10$, Methylocystis sp. MitZ-2018; 11, Methylocystis sp. SB2. 


\subsection{Methanotrophic Pathway}

Two gene clusters coding isozymes of pMMO were found in the genome of strain B8. Genes coding for sMMO were not found. The pMMO types were classified using a phylogenic tree (Figure 2). The two pMMO operons, pmoCAB1 and pmoCAB2, coded low-affinity methane oxidation (LAMO) and high-affinity methane oxidation (HAMO), respectively. Additionally, three singleton pmoC paralogs were found in the genome of strain B8. Genes related to $C_{1}$ compound metabolism are shown in Supplementary Table S4. Previous studies have reported that additional gene copies of pmoC are essential for methanotrophic growth [72,77]. Furthermore, Matsen et al. [78] suggested that the role of PmoC paralogs might be related to the regulation of gene expression or methane sensing, rather than catalytic activity.

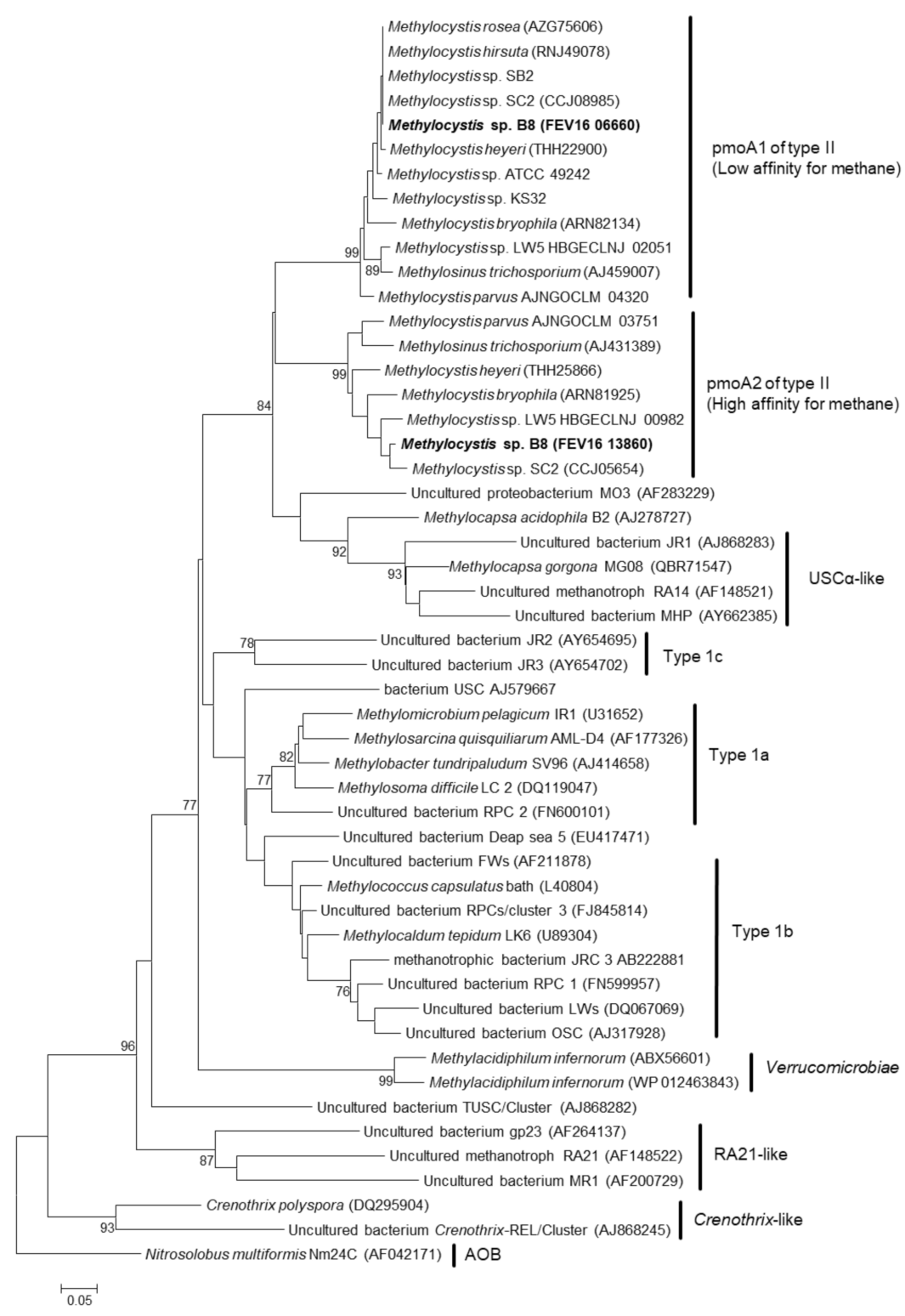

Figure 2. Phylogenetic tree of PmoA of strain B8 and related strains. The phylogenetic tree was reconstructed using the neighbor-joining method. The outgroup was AmoA of Nitrosolobus multiformis Mm24C. The clades (right side of the tree) of PmoA was classified according to Cai et al. [79]. Bootstrap values below $70 \%$ are not shown. Bar: 0.05 substitutions per amino acid site. 
The expressions of the HAMO and LAMO genes are regulated by environmental methane concentration [80]. Methanotrophs harboring both HAMO and LAMO enzymes can modify their behavior depending on methane concentration and adapt to various situations. Both types of pMMO were detected in Methylocystis sp. SC2, M. heyeri, M. parvus, and M. bryophila S285 (Supplementary Table S5). M. bryophila, M. heyeri, and M. hirsuta also had sMMO. The presence of HAMO and LAMO in the genome of strain B8 might indicate the potential of the strain to survive various methane conditions. In addition, several studies have reported that methanotrophs (especially the Methylocystis/Methylosinus group) with HAMO activity contribute to the oxidation of atmospheric methane concentrations in soil $[79,81]$. The utilization of atmospheric methane by strain B8 needs to be demonstrated in a future study.

Methanol dehydrogenase types can be classified depending on whether calcium $(M x a)$ or lanthanides (Xox) are required for activity [82-85]. Both Mxa, and Xox were detected in strain B8 (Supplementary Table S5). All the evaluated strains, except for KS32, had both Mxa and Xox (Supplementary Table S5). XoxF reportedly oxidizes methanol to formate rather than formaldehyde [85], although disparate results were recently published [86]. One study reported that the gene expression of Mxa and Xox in Methylobacter tundripaludum may change depending on the partner microbes [87]. The function of XoxF in Methylocystis requires further study. The XoxF and MxaFI methanol dehydrogenases require pyrroloquinoline quinone (PQQ) as a catalytic cofactor [88,89]. The genome of strain $\mathrm{B} 8$ contained the genes $p q q B C E$ and $p q q A$, which are required for PQQ biosynthesis. The following steps are described in the Supplementary Information.

\subsection{Nitrogen Metabolism}

Most methanotrophs possess genes related to nitrogen fixation [90-92]. Molybdenum-iron (Mo-Fe) nitrogenase was observed in all the genomes of Methylocystis. Vanadium-iron (V-Fe) nitrogenases were only found in other methanotrophic bacteria from wetland ecosystems (i.e., M. heyeri $\mathrm{H} 2{ }^{\mathrm{T}}$, M. bryophila S285, and M. parous BRSC2) [76]. Although strain B8 was obtained from wetlands, it only had genes related to molybdenum-iron (Mo-Fe) nitrogenase. These organisms can assimilate various nitrogen sources, including nitrate, nitrite, and ammonia [34,44,93]. In this study, genes related to nitrogen utilization were found in the genome of strain B8 (Supplementary Table S6). These included assimilatory nitrate/nitrite reduction-related genes, nitrate reductase (FEV16_06420) and nitrite reductase (FEV16_12950) genes, and genes for ammonium transport. These findings suggest that strain $\mathrm{B} 8$ could utilize $\mathrm{N}_{2}$, nitrate, nitrite, and ammonia as nitrogen sources. Strain B8 also harbored genes coding for hydroxylamine oxidoreductase (FEV16_03625 and FEV16_12730), which oxidizes hydroxylamine to nitrite, and hydroxylamine reductase (FEV16_04040), which catalyzes the reduction of hydroxylamine to ammonia, as observed in Methylocystis sp. SC2 [72]. These enzymes have roles in hydroxylamine detoxification as well as nitrogen acquisition.

\subsection{Hydrogenase}

Genes coding for hydrogenase and accessory proteins were observed in all Methylocystis genomes except Methylocystis sp. KS32. The phylogenetic tree, constructed using the hydrogenase gene sequences (Figure 3), revealed a variation in hydrogenase types within this genus. Methylocystis sp. SC2, which is known to use hydrogen as an energy source, had five types of hydrogenase: Ia, Id, $2 b, 3 b$, and $1 \mathrm{~h} / 5$ group hydrogenase. Among these genes, $1 \mathrm{~d}$ and $2 \mathrm{~b}$ group hydrogenases were related to hydrogen utilization by a proteomic study [48]. However, strain B8 had only two groups of hydrogenases, FEV16_01595 and FEV16_11060, which belonged to the 1h/5 and 3b groups, respectively. Nickel (Ni) and iron $(\mathrm{Fe})$ ions are present in both active sites of hydrogenases [94-96]. Hydrogen utilization was not observed in strain B8 in our experiments, but hydrogen was produced. The production is hydrogen may have been related to the $3 \mathrm{~b}$ group hydrogenase. The $3 \mathrm{~b}$ group hydrogenases reversibly reduce $\mathrm{NAD}^{+}$coupled to $\mathrm{H}_{2}$ oxidation [97]. The membrane-bound $1 \mathrm{~h} / 5$ group hydrogenases are used for aerobic respiration under starvation conditions [97]. It has been hypothesized that hydrogen might be 
used under starvation conditions. In this study, we demonstrated the hydrogen production potential of B8, a type II methanotroph. The utilization and production of $\mathrm{H}_{2}$ in strain $\mathrm{B} 8$ need further research in combination with omics studies. The produced hydrogen by methanotrophs in oxygen-limited environments might be an energy source for non-methanotrophs [27].

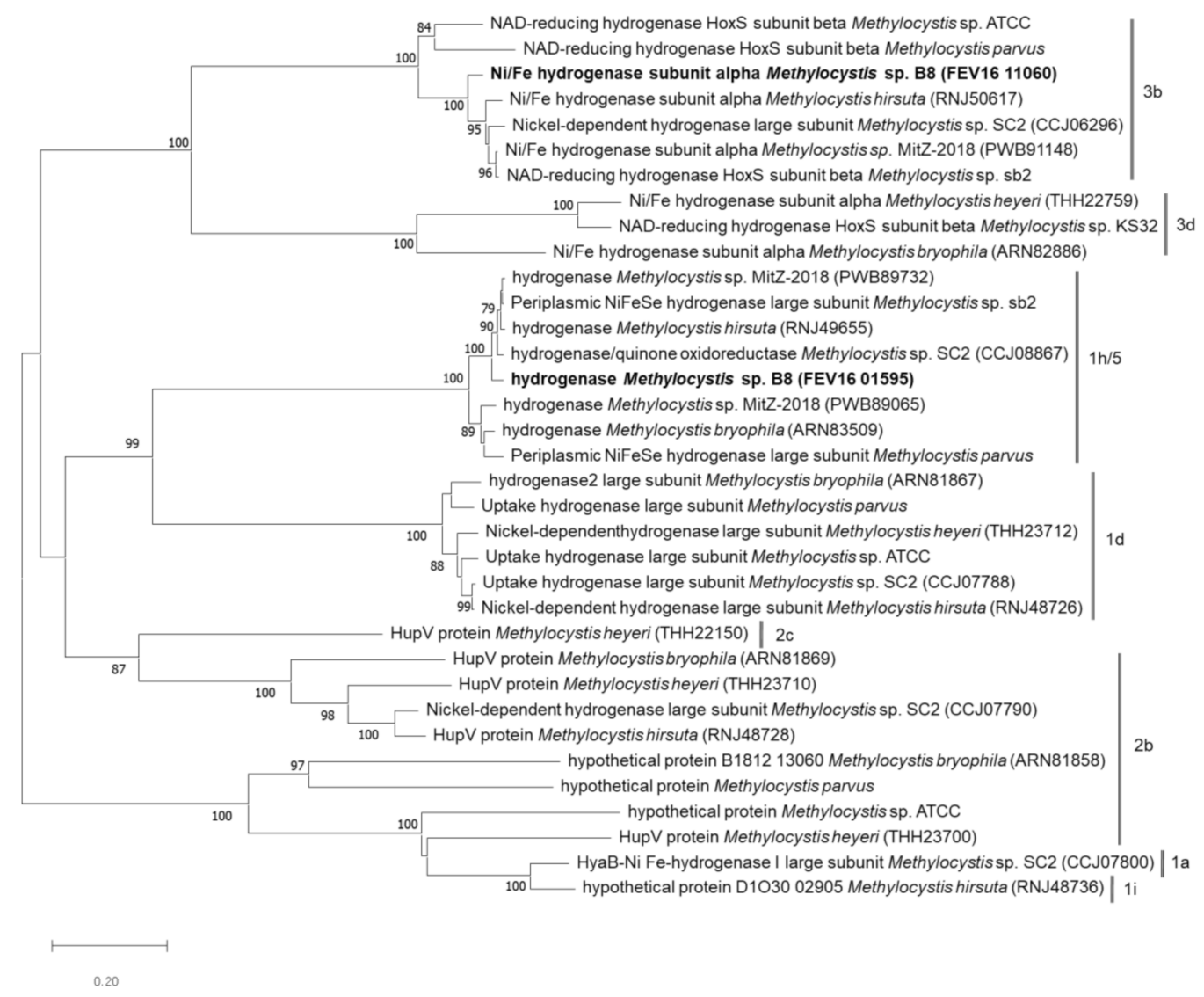

Figure 3. Phylogenetic tree of hydrogenase based on the amino acid sequences of Methylocystis sp. B8 and other strains. The tree was constructed with MEGA7 using the neighbor-joining method. These enzymes were classified into eight groups (3b, 3d, 1h/5, 1d, 2c, 2b, 1a, and 1i). Bootstrap values below $70 \%$ are not shown. Bar: 0.2 substitutions per amino acid site.

\subsection{Polyhydroxybutyrate (PHB) Synthesis}

Some methanotrophs can synthesize biopolymers, such as $\mathrm{PHB}$, to store carbon and as energy sources [98,99]. Strain B8 was expected to be able to produce and accumulate PHBs because of the presence of genes related to PHB synthesis and degradation. These genes included two poly $\beta$-hydroxybutyrate polymerases (FEV16_00425 and 06360), two poly $\beta$-hydroxybutyrate depolymerases (FEV16_05615 and 5645), acetyl-CoA acetyltransferase (FEV16_02735), acetoacetyl-CoA reductases (FEV16_02730), polyhydroxyalkanoate synthesis repressors (FEV16_02740), and three phasins (FEV16_07845, 13905, and 15530) (Supplementary Table S7). Storing PHB could lead to a reducing power when cells are starved $[99,100]$. Biodegradable and biocompatible artificial biopolymers have been developed to replace plastics derived from petroleum [99,101]. The production of PHB-based bioplastics from methane could be advantageous in terms of preventing environmental pollution.

\subsection{Resistance Genes}

Genes for glutaredoxin-dependent arsenate reductase (FEV16_04625, FEV16_04855, and FEV16_04965) and the arsenite efflux pump (FEV16_04970) involved in neutralization or exporting arsenic were demonstrated in strain B8. Arsenic is an especially toxic heavy metal because of its 
characteristic resemblance to phosphorus [102,103]. Further, arsenic is a redox-sensitive element with a geogenic origin [104]. The detoxification mechanism of arsenic might be necessary for survival in wetlands that feature large redox fluctuations.

Genes for cyanide detoxification were detected in strain B8. Cyanide is lethal to cells because it interrupts the electron transport systems and halts cellular energy production. Many organisms have defense mechanisms to neutralize cyanide $[105,106]$. The genes in strain B8 include those coding 3-mercaptopyruvate sulfurtransferase (FEV16_02590 and FEV16_16540) and rhodanese (FEV16_09915, FEV16_10965, and FEV16_13300), which catalyze the conversion of cyanide to thiocyanate.

Mercury is a toxic heavy metal, and many organisms have a mechanism to neutralize mercury toxicity [107]. Genes related to mercury detoxification, including mercury reductase (FEV16_05105, FEV16_14585, FEV16_14590, FEV16_14595, FEV16_14600, FEV16_15400, and FEV16_15405), were detected in the genome of strain B8. Mercury (II) reductase catalyzes the reduction of mercury $\left(\mathrm{Hg}^{2+}\right)$ to the less toxic elemental mercury $\left(\mathrm{Hg}^{0}\right)$. In addition, methanobactin $(\mathrm{Mbn})$ was included in this genome (See Supplementary Information and Supplementary Figure S4). Mbn is needed under copper-limited conditions and can also be used for mercury detoxification [108]. In the genus Methylocystis, genes for mercury reduction have also been demonstrated in M. rosea, Methylocystis sp. KS32, M. hirsuta, Methylocystis sp. ATCC 49,242, and Methylocystis sp. MitZ-2018 (Table 4). The potential for mercury reduction as a means of detoxification in Methylocystis sp. HL18 was suggested based on metagenomic analysis [109]. Methylococcus capsulatus Bath (type X methanotroph) showed mercury reduction activity [110]. Methylosinus trichosporium OB3b can demethylate methylmercury but does not reduce mercury [111]. Further studies are needed to confirm the mercury reduction activity (including the demethylation of methylmercury) in Methylocystis.

Table 4. Genes related to heavy metal detoxification in Methylocystis sp. B8 and related species.

\begin{tabular}{|c|c|c|c|c|c|c|c|c|c|c|c|c|}
\hline Heavy Metal Related Genes & 1 & 2 & 3 & 4 & 5 & 6 & 7 & 8 & 9 & 10 & 11 & 12 \\
\hline Mercury reductase $(m e r A)$ & + & + & + & + & + & - & + & - & - & - & + & - \\
\hline Arsenate reductase (arsC) & + & + & + & + & + & + & + & + & + & + & + & + \\
\hline Arsenite oxidase & - & - & - & + & - & - & - & - & - & - & - & - \\
\hline Arsenite methyltransferase & - & - & - & - & - & - & + & - & - & - & - & - \\
\hline Arsenite efflux transporter & + & - & - & - & + & - & - & - & - & - & - & - \\
\hline Cobalt-zinc-cadmium resistance protein & - & + & - & - & - & + & + & - & - & + & - & + \\
\hline Tellurite resistance protein & + & - & + & - & + & - & - & - & + & - & - & - \\
\hline Copper resistance protein & + & + & + & + & + & + & + & + & + & - & + & + \\
\hline
\end{tabular}

Strains: 1, Methylocystis sp. B8; 2, Methylocystis sp. ATCC 49242;3, M. hirsuta CSC1 ${ }^{\mathrm{T}} ; 4$, Methylocystis sp. SC2; 5 , M. rosea $\mathrm{SV}^{\mathrm{T}} ; 6$, M. parvus OBBP ${ }^{\mathrm{T}} ; 7$, Methylocystis sp. KS32; 8, M. bryophila H2s ${ }^{\mathrm{T}} ;$, M. heyeri $\mathrm{H} 2^{\mathrm{T}} ; 10$, Methylocystis sp. LW5; 11, Methylocystis sp. MitZ-2018; 12, Methylocystis sp. SB2. +, positive; -, negative.

The genome had genes related to tetracycline and quinolone antibiotic resistance gene (FEV16_04740) based on CARD.

\section{Conclusions}

The physiological and metabolic properties and genomic information of a facultative methanotrophic bacterial strain isolated from a wetland were determined. Phylogenetic/phylogenomic analysis and ANI and AAI values indicated that strain B8 is a novel species in the genus Methylocystis. The physiological and genomic analysis demonstrated the versatility of strain B8 in the adaptation to diverse environments. The presence of genes coding HAMO and LAMO indicated that B8 could survive under fluctuating methane concentrations. Strain B8 also harbors genes coding for hydrogenase to produce hydrogen under oxygen-limited conditions. The presence of genes for heavy metal resistance and PHB formation might be useful for survival under stress conditions. These collective features 
suggest the ubiquitous distribution of strain B8-like methanotrophs and their active roles in methane cycles in wetlands.

Supplementary Materials: The following are available online at http://www.mdpi.com/2076-2607/8/11/1719/s1. Figure S1: The cells observed with (a) DIC microscopy and (b) fluorescence microscopy stained by Nile red. Figure S2: Monitoring of methane and hydrogen concentrations in headspace of bottles. Methane concentrations in (a) hydrogen non-amended sets and (b) hydrogen-amended sets, hydrogen concentrations in (c) hydrogen non-amended sets and (b) hydrogen-amended sets, and optical density $\left(\mathrm{OD}_{600}\right)$ of (e) non-amended hydrogen sets and (f) hydrogen-amended sets with $200 \mu \mathrm{L}$ sample using Spectra Max 190 microplate reader. Figure S3: The phylogenetic tree of Methylocystis sp. B8 and other strains in the family Methylocystaceae based on the 16S ribosomal RNA gene. The phylogenetic tree was reconstructed using the neighbor-joining method. The outgroup were Rhizobium leguminosarum and Sphingomonas aestuarii in the family Rhizobiaceae and Sphingomonadaceae respectively. Bootstrap values below $70 \%$ are not shown. Bar, 0.01 substitutions per nucleotide site. Figure S4: Methanobactin gene cluster of strain B8 and other Methylocystis species. Table S1. COG classification of the genome of strain B8. Table S2: AAI results of the genera Methylocystis and Methylosinus (excel). Table S3: COG classification based on the pan-genome and core-genome of the genus Methylocystis and the unique clusters of strain B8. Table S4: Genes related to $C_{1}$ compound metabolism in strain B8. Table S5: Comparative analysis of genes related to methane and methanol utilization in Methylocystis. Table S6: Genes related to nitrogen metabolism in strain B8. Table S7: Genes related to PHB formation in strain B8.

Author Contributions: G.-Y.J.: investigation (lead); visualization (equal); writing-original draft preparation (lead); S.-K.R.: supervision (lead); writing-review and editing (equal); Y.-S.H.: investigation (equal); S.-J.K.: conceptualization (equal); data curation (lead); visualization (equal); writing-review and editing (equal). All authors have read and agreed to the published version of the manuscript.

Funding: This work was supported by the Basic Research Project of the Korea Institute of Geoscience and Mineral Resources (20-3412-1), Republic of Korea and the National Research Council of Science \& Technology (NST) grant by the Korean government (MSIP) (Project code: CAP-19-05-KIGAM).

Conflicts of Interest: The authors declare no conflict of interest.

\section{References}

1. Whiting, G.J.; Chanton, J.P. Primary production control of methane emission from wetlands. Nat. Cell Biol. 1993, 364, 794-795. [CrossRef]

2. Mitsch, W.J.; Bernal, B.; Nahlik, A.M.; Mander, Ü.; Zhang, L.; Anderson, C.J.; Jorgensen, S.E.; Brix, H. Wetlands, carbon, and climate change. Landsc. Ecol. 2012, 28, 583-597. [CrossRef]

3. Shao, X.; Sheng, X.; Wu, M.; Wu, H.; Ning, X. Methane production potential and emission at different water levels in the restored reed wetland of Hangzhou Bay. PLoS ONE 2017, 12, e0185709. [CrossRef] [PubMed]

4. Kirschke, S.; Bousquet, P.; Ciais, P.; Saunois, M.; Canadell, J.G.; Dlugokencky, E.; Bergamaschi, P.; Bergmann, D.; Blake, D.R.; Bruhwiler, L.M.P.; et al. Three decades of global methane sources and sinks. Nat. Geosci. 2013, 6, 813-823. [CrossRef]

5. Bastviken, D.; Cole, J.; Pace, M.; Tranvik, L. Methane emissions from lakes: Dependence of lake characteristics, two regional assessments, and a global estimate. Glob. Biogeochem. Cycles 2004, 18, 18. [CrossRef]

6. Conrad, R. The global methane cycle: Recent advances in understanding the microbial processes involved. Environ. Microbiol. Rep. 2009, 1, 285-292. [CrossRef] [PubMed]

7. King, G.M. Ecological aspects of methane oxidation, a key determinant of global methane dynamics. In Advances in Microbial Ecology; Springer: Berlin, Germany, 1992; pp. 431-468.

8. Chowdhury, T.R.; Dick, R.P. Ecology of aerobic methanotrophs in controlling methane fluxes from wetlands. Appl. Soil Ecol. 2013, 65, 8-22. [CrossRef]

9. Stocker, T.F.; Qin, D.; Plattner, G.-K.; Tignor, M.; Allen, S.K.; Boschung, J.; Nauels, A.; Xia, Y.; Bex, V.; Midgley, P.M. Climate change 2013: The physical science basis. Contribution of working group I to the fifth assessment report of the intergovernmental panel on climate change. In Evaluation of Climate Models; Cambridge University Press: Cambridge, UK, 2013; p. 1535.

10. Dedysh, S.N.; Eknief, C. Diversity and phylogeny of described aerobic methanotrophs. In Methane Biocatalysis: Paving the Way to Sustainability; Springer: Berlin, Germany, 2018; pp. 17-42.

11. Semrau, J.D.; DiSpirito, A.A.; Yoon, S. Methanotrophs and copper. FEMS Microbiol. Rev. 2010, 34, 496-531. [CrossRef]

12. Hanson, R.S. The obligate methanotrophic bacteria Merhvlococcus. Methylomonas, and Methylosinus. In The Procaryotes; Springer: Berlin, Germany, 1992; pp. 2350-2364. 
13. Oremland, R.S.; Culbertson, C.W. Importance of methane-oxidizing bacteria in the methane budget as revealed by the use of a specific inhibitor. Nat. Cell Biol. 1992, 356, 421-423. [CrossRef]

14. Dalton, H. Methane Oxidation by Methanotrophs. In Methane and Methanol Utilizers; Springer: Berlin, Germany, 1992; pp. 85-114.

15. Murrell, J.C.; Gilbert, B.; McDonald, I.R. Molecular biology and regulation of methane monooxygenase. Arch. Microbiol. 2000, 173, 325-332. [CrossRef]

16. Fox, B.G.; Afroland, W.; Jollie, D.R.; Lipscomb, J.D. Methane monooxygenase from Methylosinus trichosporium OB3b. Methods Enzymol. 1990, 188, 191-202. [CrossRef] [PubMed]

17. DeWitt, J.G.; Bentsen, J.G.; Rosenzweig, A.C.; Hedman, B.; Green, J.; Pilkington, S.; Papaefthymiou, G.C.; Dalton, H.; Hodgson, K.O.; Lippard, S.J. X-ray absorption, Moessbauer, and EPR studies of the dinuclear iron center in the hydroxylase component of methane monooxygenase. J. Am. Chem. Soc. 1991, 113, 9219-9235. [CrossRef]

18. Nguyen, H.H.; Shiemke, A.K.; Jacobs, S.J.; Hales, B.J.; Lidstrom, M.E.; Chan, S.I. The nature of the copper ions in the membranes containing the particulate methane monooxygenase from Methylococcus capsulatus (Bath). J. Biol. Chem. 1994, 269, 14995-15005.

19. Anthony, C.; Zatman, L.J. The microbial oxidation of methanol. The prosthetic group of the alcohol dehydrogenase of Pseudomonas sp. M27: A new oxidoreductase prosthetic group. Biochem. J. 1967, 104, 960-969. [CrossRef]

20. Vorholt, J.A.; Chistoserdova, L.; Lidstrom, M.E.; Thauer, R.K. The NADP-dependent methylene tetrahydromethanopterin dehydrogenase in Methylobacterium extorquens AM1. J. Bacteriol. 1998, 180, 5351-5356. [CrossRef]

21. Marx, C.J.; Chistoserdova, L.; Lidstrom, M.E. Formaldehyde-detoxifying role of the tetrahydromethanopterin-linked pathway in Methylobacterium extorquens AM. J. Bacteriol. 2003, 185, 7160-7168. [CrossRef]

22. Chistoserdova, L.; VanWiggeren, G.D.; Roy, R. C1 transfer enzymes and coenzymes linking methylotrophic bacteria and methanogenic archaea. Science 1998, 281, 99-102. [CrossRef]

23. Strong, P.J.; Xie, S.; Clarke, W.P. Methane as a resource: Can the methanotrophs add value? Environ. Sci. Technol. 2015, 49, 4001-4018. [CrossRef]

24. Haynes, C.A.; Gonzalez, R. Rethinking biological activation of methane and conversion to liquid fuels. Nat. Chem. Biol. 2014, 10, 331-339. [CrossRef]

25. Bordel, S.; Rojas, A.; Muñoz, R. Reconstruction of a genome scale metabolic model of the polyhydroxybutyrate producing methanotroph Methylocystis parvus OBBP. Microb. Cell Factories 2019, 18, 1-11. [CrossRef] [PubMed]

26. Strong, P.J.; Laycock, B.; Mahamud, S.N.S.; Jensen, P.D.; Lant, P.A.; Tyson, G.W.; Pratt, S. The opportunity for high-performance biomaterials from methane. Microorganisms 2016, 4, 11. [CrossRef]

27. Kalyuzhnaya, M.G.; Yang, S.; Rozova, O.N.; Smalley, N.E.; Clubb, J.; Lamb, A.; Gowda, G.A.N.; Raftery, D.; Fu, Y.; Bringel, F.; et al. Highly efficient methane biocatalysis revealed in a methanotrophic bacterium. Nat. Commun. 2013, 4, 1-7. [CrossRef]

28. Bowman, J.P.; Sly, L.I.; Nichols, P.D.; Hayward, A.C. Revised taxonomy of the methanotrophs: Description of Methylobacter gen. nov., emendation of Methylococcus, validation of Methylosinus and Methylocystis species, and a proposal that the family Methylococcaceae includes only the group I methanotrophs. Int. J. Syst. Bacteriol. 1993, 43, 735-753. [CrossRef]

29. Whittenbury, R.; Davies, S.L.; Davey, J.F. Exospores and cysts formed by methane-utilizing bacteria. J. Gen. Microbiol. 1970, 61, 219-226. [CrossRef] [PubMed]

30. Wartiainen, I.; Hestnes, A.G.; McDonald, I.R.; Svenning, M.M. Methylocystis rosea sp. nov., a novel methanotrophic bacterium from Arctic wetland soil, Svalbard, Norway $\left(78^{\circ} \mathrm{N}\right)$. Int. J. Syst. Evol. Microbiol. 2006, 56, 541-547. [CrossRef] [PubMed]

31. Lindner, A.S.; Pacheco, A.; Aldrich, H.C.; Staniec, A.C.; Uz, I.; Hodson, D.J. Methylocystis hirsuta sp. nov., a novel methanotroph isolated from a groundwater aquifer. Int. J. Syst. Evol. Microbiol. 2007, 57, 1891-1900. [CrossRef] [PubMed]

32. Belova, S.E.; Kulichevskaya, I.S.; Bodelier, P.L.E.; Dedysh, S.N. Methylocystis bryophila sp. nov., a facultatively methanotrophic bacterium from acidic Sphagnum peat, and emended description of the genus Methylocystis (ex Whittenbury et al. 1970) Bowman et al. Int. J. Syst. Evol. Microbiol. 2013, 63, 1096-1104. [CrossRef] 
33. Dedysh, S.N.; Belova, S.E.; Bodelier, P.L.E.; Smirnova, K.V.; Khmelenina, V.N.; Chidthaisong, A.; Trotsenko, Y.A.; Liesack, W.; Dunfield, P.F. Methylocystis heyeri sp. nov., a novel type II methanotrophic bacterium possessing 'signature' fatty acids of type I methanotrophs. Int. J. Syst. Evol. Microbiol. 2007, 57, 472-479. [CrossRef]

34. Dam, B.; Dam, S.; Blom, J.; Liesack, W. Genome analysis coupled with physiological studies reveals a diverse nitrogen metabolism in Methylocystis sp. strain SC2. PLoS ONE 2013, 8, e74767. [CrossRef]

35. Stein, L.Y.; Bringel, F.; DiSpirito, A.A.; Han, S.; Jetten, M.S.M.; Kalyuzhnaya, M.G.; Kits, K.D.; Klotz, M.G.; Camp, H.J.M.O.D.; Semrau, J.D.; et al. Genome sequence of the methanotrophic alphaproteobacterium Methylocystis sp. Strain Rockwell (ATCC 49242). J. Bacteriol. 2011, 193, 2668-2669. [CrossRef]

36. Han, D.; Dedysh, S.N.; Liesack, W. Unusual genomic traits suggest Methylocystis bryophila S285 to be well adapted for life in peatlands. Genome Biol. Evol. 2018, 10, 623-628. [CrossRef] [PubMed]

37. Nguyen, N.-L.; Yu, W.-J.; Gwak, J.-H.; Kim, S.-J.; Park, S.-J.; Herbold, C.W.; Kim, J.-G.; Jung, M.-Y.; Rhee, S.-K. Genomic insights into the acid adaptation of novel methanotrophs enriched from acidic forest soils. Front. Microbiol. 2018, 9, 1982. [CrossRef] [PubMed]

38. Vorobev, A.; Jagadevan, S.; Jain, S.; Anantharaman, K.; Dick, G.J.; Vuilleumier, S.; Semrau, J.D. Genomic and Transcriptomic analyses of the facultative methanotroph Methylocystis sp. Strain SB2 grown on methane or ethanol. Appl. Environ. Microbiol. 2014, 80, 3044-3052. [CrossRef] [PubMed]

39. Belova, S.E.; Baani, M.; Suzina, N.E.; Bodelier, P.L.; Liesack, W.; Dedysh, S.N. Acetate utilization as a survival strategy of peat-inhabiting Methylocystis spp. Environ. Microbiol. Rep. 2011, 3, 36-46. [CrossRef]

40. Knief, C.; Dunfield, P.F. Response and adaptation of different methanotrophic bacteria to low methane mixing ratios. Environ. Microbiol. 2005, 7, 1307-1317. [CrossRef]

41. Dunfield, P.F. The soil methane sink. In Greenhouse Gas Sinks; CABI: Wallingford, CT, USA, 2009; pp. 152-170. [CrossRef]

42. Smith, E.J.; Davison, W.; Hamilton-Taylor, J. Methods for preparing synthetic freshwaters. Water Res. 2002, 36, 1286-1296. [CrossRef]

43. Widdel, F.; Bak, F. Gram-Negative Mesophilic sulfate-reducing bacteria. In The Prokaryotes; Springer: Berlin, Germany, 1992; pp. 3352-3378.

44. Whittenbury, R.; Phillips, K.C.; Wilkinson, J.F. Enrichment, isolation and some properties of methane-utilizing bacteria. J. Gen. Microbiol. 1970, 61, 205-218. [CrossRef]

45. Kim, S.-J.; Park, S.-J.; Cha, I.-T.; Min, D.; Kim, J.-S.; Chung, W.-H.; Chae, J.-C.; Jeon, C.O.; Rhee, S.-K. Metabolic versatility of toluene-degrading, iron-reducing bacteria in tidal flat sediment, characterized by stable isotope probing-based metagenomic analysis. Environ. Microbiol. 2013, 16, 189-204. [CrossRef]

46. Jung, M.-Y.; Park, S.-J.; Min, D.; Kim, J.-S.; Rijpstra, W.I.C.; Damsté, J.S.S.; Kim, G.-J.; Madsen, E.L.; Rhee, S.-K. Enrichment and characterization of an autotrophic ammonia-oxidizing archaeon of mesophilic crenarchaeal group I.1a from an agricultural soil. Appl. Environ. Microbiol. 2011, 77, 8635-8647. [CrossRef]

47. Holmes, A.J.; Costello, A.; Lidstrom, M.E.; Murrell, J.C. Evidence that participate methane monooxygenase and ammonia monooxygenase may be evolutionarily related. FEMS Microbiol. Lett. 1995, 132, $203-208$. [CrossRef]

48. Hakobyan, A.; Zhu, J.; Glatter, T.; Paczia, N.; Liesack, W. Hydrogen utilization by Methylocystis sp. strain SC2 expands the known metabolic versatility of type Ila methanotrophs. Metab. Eng. 2020, 61, 181-196. [CrossRef] [PubMed]

49. Lane, D. 16S/23S rRNA sequencing. In Nucleic Acid Techniques in Bacterial Systematics; Wiley: Hoboken, NJ, USA, 1991; pp. 115-175.

50. Weisburg, W.G.; Barns, S.M.; Pelletier, D.A.; Lane, D.J. 16 S ribosomal DNA amplification for phylogenetic study. J. Bacteriol. 1991, 173, 697-703. [CrossRef] [PubMed]

51. Miguez, C.; Bourque, D.; Sealy, J.; Greer, C.; Groleau, D. Detection and isolation of methanotrophic bacteria possessing soluble methane monooxygenase (sMMO) genes using the polymerase chain reaction (PCR). Microb. Ecol. 1997, 33, 21-31. [CrossRef] [PubMed]

52. Hutchens, E.; Radajewski, S.; Dumont, M.G.; McDonald, I.R.; Murrell, J.C. Analysis of methanotrophic bacteria in Movile Cave by stable isotope probing. Environ. Microbiol. 2003, 6, 111-120. [CrossRef]

53. Saitou, N.; Nei, M. The neighbor-joining method: A new method for reconstructing phylogenetic trees. Mol. Biol. Evol. 1987, 4, 406-425. [CrossRef] 
54. Lewis, P.O.; Kumar, S.; Tamura, K.; Nei, M. MEGA: Molecular evolutionary genetics analysis, Version 1.02. Syst. Biol. 1995, 44, 576. [CrossRef]

55. Yoon, S.-H.; Ha, S.-M.; Kwon, S.; Lim, J.; Kim, Y.; Seo, H.; Chun, J. Introducing EzBioCloud: A taxonomically united database of $16 \mathrm{~S}$ rRNA gene sequences and whole-genome assemblies. Int. J. Syst. Evol. Microbiol. 2017, 67, 1613-1617. [CrossRef]

56. Bankevich, A.; Nurk, S.; Antipov, D.; Gurevich, A.A.; Dvorkin, M.; Kulikov, A.S.; Lesin, V.M.; Nikolenko, S.I.; Pham, S.; Prjibelski, A.D.; et al. SPAdes: A new genome assembly algorithm and its applications to single-cell sequencing. J. Comput. Biol. 2012, 19, 455-477. [CrossRef]

57. Tatusova, T.; DiCuccio, M.; Badretdin, A.; Chetvernin, V.; Nawrocki, E.P.; Zaslavsky, L.; Lomsadze, A.; Pruitt, K.D.; Borodovsky, M.; Ostell, J. NCBI prokaryotic genome annotation pipeline. Nucleic Acids Res. 2016, 44, 6614-6624. [CrossRef]

58. Camacho, C.; Coulouris, G.; Avagyan, V.; Ma, N.; Papadopoulos, J.S.; Bealer, K.; Madden, T.L. BLAST+: Architecture and applications. BMC Bioinform. 2009, 10, 421. [CrossRef]

59. Kanehisa, M.; Furumichi, M.; Tanabe, M.; Sato, Y.; Morishima, K. KEGG: New perspectives on genomes, pathways, diseases and drugs. Nucleic Acids Res. 2016, 45, D353-D361. [CrossRef]

60. Mistry, J.; Bateman, A.; Finn, R.D. Predicting active site residue annotations in the Pfam database. BMC Bioinform. 2007, 8, 1-14. [CrossRef]

61. Lee, I.; Kim, Y.O.; Park, S.-C.; Chun, J. OrthoANI: An improved algorithm and software for calculating average nucleotide identity. Int. J. Syst. Evol. Microbiol. 2016, 66, 1100-1103. [CrossRef] [PubMed]

62. Zhao, Y.; Wu, J.; Yang, J.; Sun, S.; Xiao, J.; Yu, J. PGAP: Pan-genomes analysis pipeline. Bioinformatics 2011, 28, 416-418. [CrossRef] [PubMed]

63. Eren, A.M.; Esen, Ö.C.; Quince, C.; Vineis, J.H.; Morrison, H.G.; Sogin, M.L.; Delmont, T.O. Anvi'o: An advanced analysis and visualization platform for omics data. Peer] 2015, 3, e1319. [CrossRef] [PubMed]

64. Alcock, B.P.; Raphenya, A.R.; Lau, T.T.Y.; Tsang, K.K.; Bouchard, M.; Edalatmand, A.; Huynh, W.; Nguyen, A.-L.V.; Cheng, A.A.; Liu, S.; et al. CARD 2020: Antibiotic resistome surveillance with the comprehensive antibiotic resistance database. Nucleic Acids Res. 2020, 48, D517-D525. [CrossRef]

65. Lee, S.-P.; Park, J.-C. Management of organic matters by constructed treatment wetlands during rainfall events. J. Environ. Sci. Int. 2017, 26, 401-410. [CrossRef]

66. Kwon, J.-H.; Han, Y.-S.; Cho, Y.-C.; Ahn, J.-S.; Yim, G.-J. Water Quality and Methane emission characteristics of aerobic wetlands constructed in coal mine area. J. Korean Soc. Miner. Energy Resour. Eng. 2018, 55, 371-382. [CrossRef]

67. Im, J.; Lee, S.-W.; Yoon, S.; DiSpirito, A.A.; Semrau, J.D. Characterization of a novel facultative Methylocystis species capable of growth on methane, acetate and ethanol. Environ. Microbiol. Rep. 2010, 3, 174-181. [CrossRef]

68. Reid, R.; Mosley, L.M. Comparative contributions of solution geochemistry, microbial metabolism and aquatic photosynthesis to the development of high $\mathrm{pH}$ in ephemeral wetlands in South East Australia. Sci. Total. Environ. 2016, 542, 334-343. [CrossRef]

69. Dianou, D.; Adachi, K.; Dianou, D. Characterization of methanotrophic bacteria isolated from a subtropical paddy field. FEMS Microbiol. Lett. 1999, 173, 163-173. [CrossRef]

70. Hou, C.T.; Laskin, A.I.; Patel, R.N. Growth and polysaccharide production by Methylocystis parvus OBBP on methanol. Appl. Environ. Microbiol. 1979, 37, 800-804. [CrossRef]

71. Jo, S.Y.; Na Rhie, M.; Jung, S.M.; Sohn, Y.J.; Yeon, Y.J.; Kim, M.-S.; Park, C.; Lee, J.; Park, S.J.; Na, J.-G. Hydrogen production from methane by Methylomonas sp. DH-1 under micro-aerobic conditions. Biotechnol. Bioprocess Eng. 2020, 25, 71-77. [CrossRef]

72. Dam, B.; Kube, M.; Dam, S.; Reinhardt, R.; Liesack, W. Complete sequence analysis of two methanotroph-specific repABC-containing plasmids from Methylocystis sp. strain SC2. Appl. Environ. Microbiol. 2012, 78, 4373-4379. [CrossRef] [PubMed]

73. Konstantinidis, K.T.; Tiedje, J.M. Towards a genome-based taxonomy for prokaryotes. J. Bacteriol. 2005, 187, 6258-6264. [CrossRef]

74. Konstantinidis, K.T.; Ramette, A.N.; Tiedje, J.M. The bacterial species definition in the genomic era. Philos. Trans. R. Soc. B Biol. Sci. 2006, 361, 1929-1940. [CrossRef]

75. Tatusov, R.L.; Koonin, E.V.; Lipman, D.J. A Genomic perspective on protein families. Science 1997, 278, 631-637. [CrossRef] 
76. Oshkin, I.Y.; Miroshnikov, K.K.; Grouzdev, D.S.; Dedysh, S.N. Pan-genome-based analysis as a framework for demarcating two closely related methanotroph genera Methylocystis and Methylosinus. Microorganisms 2020, 8, 768. [CrossRef]

77. Stolyar, S.; Costello, A.M.; Peeples, T.L.; Lidstrom, M.E. Role of multiple gene copies in particulate methane monooxygenase activity in the methane-oxidizing bacterium Methylococcus capsulatus Bath. Microbiology 1999, 145, 1235-1244. [CrossRef] [PubMed]

78. Matsen, J.B.; Yang, S.; Stein, L.Y.; Beck, D.A.; Kalyuzhanaya, M.G. Global molecular analyses of methane metabolism in methanotrophic alphaproteobacterium, Methylosinus trichosporium OB3b. Part I: Transcriptomic study. Front. Microbiol. 2013, 4, 40. [CrossRef]

79. Cai, Y.; Zheng, Y.; Bodelier, P.L.E.; Conrad, R.; Jia, Z. Conventional methanotrophs are responsible for atmospheric methane oxidation in paddy soils. Nat. Commun. 2016, 7, 11728. [CrossRef] [PubMed]

80. Baani, M.; Liesack, W. Two isozymes of particulate methane monooxygenase with different methane oxidation kinetics are found in Methylocystis sp. strain SC2. Proc. Natl. Acad. Sci. USA 2008, 105, 10203-10208. [CrossRef]

81. Dunfield, P.F.; Liesack, W.; Henckel, T.; Knowles, R.; Conrad, R. High-affinity methane oxidation by a soil enrichment culture containing a type II methanotroph. Appl. Environ. Microbiol. 1999, 65, 1009-1014. [CrossRef]

82. Anthony, C.; Ghosh, M.; Blake, C.C.F. The structure and function of methanol dehydrogenase and related quinoproteins containing pyrrolo-quinoline quinone. Biochem. J. 1994, 304, 665-674. [CrossRef] [PubMed]

83. Anthony, C.; Williams, P. The structure and mechanism of methanol dehydrogenase. Biochim. Biophys. Acta (BBA) Proteins Proteom. 2003, 1647, 18-23. [CrossRef]

84. Nakagawa, T.; Mitsui, R.; Tani, A.; Sasa, K.; Tashiro, S.; Iwama, T.; Hayakawa, T.; Kawai, K. A Catalytic Role of XoxF1 as $\mathrm{La}^{3+}$-dependent methanol dehydrogenase in Methylobacterium extorquens strain AM1. PLoS ONE 2012, 7, e50480. [CrossRef]

85. Keltjens, J.T.; Pol, A.; Reimann, J.; Camp, H.J.M.O.D. PQQ-dependent methanol dehydrogenases: Rare-earth elements make a difference. Appl. Microbiol. Biotechnol. 2014, 98, 6163-6183. [CrossRef]

86. Picone, N.; Camp, H.J.M.O.D. Role of rare earth elements in methanol oxidation. Curr. Opin. Chem. Biol. 2019, 49, 39-44. [CrossRef]

87. Krause, S.M.B.; Johnson, T.; Karunaratne, Y.S.; Fu, Y.; Beck, D.A.C.; Chistoserdova, L.; Lidstrom, M.E. Lanthanide-dependent cross-feeding of methane-derived carbon is linked by microbial community interactions. Proc. Natl. Acad. Sci. USA 2016, 114, 358-363. [CrossRef]

88. Salisbury, S.A.; Forrest, H.S.; Cruse, W.B.T.; Kennard, O. A novel coenzyme from bacterial primary alcohol dehydrogenases. Nat. Cell Biol. 1979, 280, 843-844. [CrossRef]

89. Anthony, C. The quinoprotein dehydrogenases for methanol and glucose. Arch. Biochem. Biophys. 2004, 428, 2-9. [CrossRef] [PubMed]

90. Murrell, J.C.; Dalton, H. Nitrogen fixation in obligate methanotrophs. Microbiology 1983, 129, 3481-3486. [CrossRef]

91. Auman, A.J.; Speake, C.C.; Lidstrom, M.E. nifH Sequences and nitrogen fixation in type I and type II methanotrophs. Appl. Environ. Microbiol. 2001, 67, 4009-4016. [CrossRef]

92. Dedysh, S.N.; Ricke, P.; Liesack, W. NifH and NifD phylogenies: An evolutionary basis for understanding nitrogen fixation capabilities of methanotrophic bacteria. Microbiology 2004, 150, 1301-1313. [CrossRef]

93. Bédard, C.; Knowles, R. Physiology, biochemistry, and specific inhibitors of $\mathrm{CH}_{4}, \mathrm{NH}_{4}{ }^{+}$, and CO oxidation by methanotrophs and nitrifiers. Microbiol. Rev. 1989, 53, 68-84. [CrossRef] [PubMed]

94. Graf, E.-G.; Thauer, R.K. Hydrogenase from methanobacterium thermoautotrophicum, a nickel-containing enzyme. FEBS Lett. 1981, 136, 165-169. [CrossRef]

95. Thauer, R.K.; Klein, A.A.R.; Hartmann, G.C. Reactions with molecular hydrogen in microorganisms: Evidence for a purely organic hydrogenation catalyst. Chem. Rev. 1996, 96, 3031-3042. [CrossRef]

96. Pavlov, M.; Siegbahn, P.E.M.; Blomberg, M.R.A.; Crabtree, R.H. Mechanism of H-H activation by nickel-iron hydrogenase. J. Am. Chem. Soc. 1998, 120, 548-555. [CrossRef]

97. Greening, C.; Biswas, A.; Carere, C.R.; Jackson, C.J.; Taylor, M.C.; Stott, M.B.; Cook, G.M.; Morales, S.E. Genomic and metagenomic surveys of hydrogenase distribution indicate $\mathrm{H}_{2}$ is a widely utilised energy source for microbial growth and survival. ISME J. 2015, 10, 761-777. [CrossRef] 
98. Cal, A.J.; Sikkema, W.D.; Ponce, M.I.; Franqui-Villanueva, D.; Riiff, T.J.; Orts, W.J.; Pieja, A.J.; Lee, C.C. Methanotrophic production of polyhydroxybutyrate-co-hydroxyvalerate with high hydroxyvalerate content. Int. J. Biol. Macromol. 2016, 87, 302-307. [CrossRef]

99. Khosravi-Darani, K.; Mokhtari, Z.-B.; Amai, T.; Tanaka, K. Microbial production of poly(hydroxybutyrate) from C1 carbon sources. Appl. Microbiol. Biotechnol. 2013, 97, 1407-1424. [CrossRef] [PubMed]

100. Byrom, D.P. Plastics from Microbes: Microbial Synthesis of Polymers and Polymer Precursors; Hanser: Munich, Germany, 1994; p. 5.

101. Braunegg, G.; Sonnleitner, B.; Lafferty, R.M. A rapid gas chromatographic method for the determination of poly-?-hydroxybutyric acid in microbial biomass. Appl. Microbiol. Biotechnol. 1978, 6, 29-37. [CrossRef]

102. Gunes, A.; Pilbeam, D.J.; Inal, A. Effect of arsenic-phosphorus interaction on arsenic-induced oxidative stress in chickpea plants. Plant Soil 2008, 314, 211-220. [CrossRef]

103. Slyemi, D.; Bonnefoy, V. How prokaryotes deal with arsenict. Environ. Microbiol. Rep. 2011, 4, 571-586. [CrossRef]

104. Herath, I.; Vithanage, M.; Bundschuh, J.; Maity, J.P.; Bhattacharya, P. Natural arsenic in global groundwaters: Distribution and geochemical triggers for mobilization. Curr. Pollut. Rep. 2016, 2, 68-89. [CrossRef]

105. Patil, Y.B.; Paknikar, K. Development of a process for biodetoxification of metal cyanides from waste waters. Process. Biochem. 2000, 35, 1139-1151. [CrossRef]

106. Gupta, N.; Balomajumder, C.; Agarwal, V.K. Enzymatic mechanism and biochemistry for cyanide degradation: A review. J. Hazard. Mater. 2010, 176, 1-13. [CrossRef]

107. Dash, H.R.; Das, S. Bioremediation of mercury and the importance of bacterial mer genes. Int. Biodeterior. Biodegrad. 2012, 75, 207-213. [CrossRef]

108. Vorobev, A.; Jagadevan, S.; Baral, B.S.; DiSpirito, A.A.; Freemeier, B.C.; Bergman, B.H.; Bandow, N.L.; Semrau, J.D. Detoxification of mercury by methanobactin from Methylosinus trichosporium OB3b. Appl. Environ. Microbiol. 2013, 79, 5918-5926. [CrossRef]

109. Shi, L.-D.; Chen, Y.-S.; Du, J.-J.; Hu, Y.-Q.; Shapleigh, J.P.; Zhao, H.-P. Metagenomic evidence for a Methylocystis species capable of bioremediation of diverse heavy metals. Front. Microbiol. 2019, 9, 3297. [CrossRef]

110. Boden, R.; Murrell, J.C. Response to mercury (II) ions in Methylococcus capsulatus (Bath). FEMS Microbiol. Lett. 2011, 324, 106-110. [CrossRef]

111. Lu, X.; Gu, W.; Zhao, L.; Haque, M.F.U.; DiSpirito, A.A.; Semrau, J.D.; Gu, B. Methylmercury uptake and degradation by methanotrophs. Sci. Adv. 2017, 3, e1700041. [CrossRef] [PubMed]

Publisher's Note: MDPI stays neutral with regard to jurisdictional claims in published maps and institutional affiliations.

(C) 2020 by the authors. Licensee MDPI, Basel, Switzerland. This article is an open access article distributed under the terms and conditions of the Creative Commons Attribution (CC BY) license (http://creativecommons.org/licenses/by/4.0/). 